\title{
The Cold War in Welfare: Stock Markets versus Pensions
}

Richard Minns

(Verso, 2001; ISBN 1-85984-625-4; 239pp; hardback; £18)

The jacket cover of this book proclaims that the book describes 'a new Cold War ... between competing blocks of countries over the role of financial markets versus the state and the provision of pensions and the financing of the economy more generally'. The jacket cover is quite accurate. The central hypothesis of the book is that, just as petrodollars were important in the financial markets of the 1970s, pension dollars are important today.

The world, Minns argues, is divided up into blocks of countries: the Anglo-American block which has well-developed capital markets; continental Europe which does not; and the Asian-Pacific which often features government intervention in capital markets. The hypothesis is that pension systems need to be considered in the context of their financial environment. The Anglo-American financial markets are hence suitable for funded pensions whereas the lack of equity markets in continental Europe leads more naturally to state provision and book reserve private pensions. The Asian Pacific model involves government management and investment of provident funds.

The book is exciting reading. The Anglo-American model is spreading, the author argues, even though there is a lack of evidence that funded pensions increase savings and that frequently the academic debate is overly political.
Minns writes: 'the allusions, innuendoes and arguments used by some academics and the World Bank are extremely tendentious and disappointing' (p. 53).

Chapters 1 and 2 introduce the book. Chapter 3 reviews Minns' typology of different countries. Chapter 4 reviews the core arguments for funded pensions and looks at the evidence. Chapter 5 outlines the political interests of fund managers and others arguing for an expansion of funded pensions. Chapter 6 assesses rate of return arguments on different pension systems. Chapter 7 reviews financial panics and the risks of equity investment. Chapters 8 and 9 follow up some of the earlier arguments.

As one would expect with such a strong thesis, there are places where there is perhaps not enough attention to opposing arguments and evidence. For instance, it argues (p. 120) about 'unproductive takeovers' as a cost of Anglo-American capital markets. However it neglects the academic literature involving Michael Jensen of Harvard University and others, which argues that takeovers and M\&A activity in the 1980s led to massive improvements in US productivity by restructuring weak US companies and replacing poor managers.

Overall, this is an interesting book to read and it is certainly thought provoking. However, the fundamental problem with the book is that its 
proposals for change are not backed up with enough detail or evidence that they would work. For instance in Chapter 10, which argues for support for economically targeted investment ( $\mathrm{p}$. 206), the literature on investment performance of public investment funds does not receive enough attention. At a minimum one would expect a much more extensive discussion of governmental structures necessary to implement socially responsible investment.

Mike Orszag

Head of Research, Watson Wyatt Partners 